\title{
PENINGKATAN KAPASITAS PENGELOLAAN MANAJEMEN KEUANGAN BAGI KELOMPOK PKK RW 01 CIPAYUNG JAYA DEPOK 1
}

\author{
Dedy Wahyudi ${ }^{1}$, Ester Dwi Wahyuni², Apriyanto ${ }^{3}$ \\ Fakultas Ekonomi dan Bisnis, Universitas Sahid Jakarta \\ Jl. Prof Dr. Supomo No 84, Jakarta Selatan \\ Email Korespondensi:dedy2r@yahoo.com
}

\begin{abstract}
ABSTRAK
Kelompok PKK RW 01 Cipayung Jaya Depok 1 merupakan kumpulan ibu-ibu rumah tangga, yang selain mengisi kegiatan sehari-harinya dengan melakukan kegiatan PKK tugas utamanya sebagai istri adalah mengelola semua pendapatan/penerimaan baik penerimaan rutin maupun tidak rutin dan pengeluaran rutin maupun pengeluaran tidak rutin sehari-hari untuk keperluan keluarganya. Masalah ibu-ibu kelompok PKK RW 01 Cipayung Jaya Depok 1 yang selalu dibicarakan adalah adanya pos-pos yang over budget sehingga terjadi defisit keuangan pada akhir bulan atau adanya kebutuhan yang tidak terpenuhi. Kondisi ini jika tidak diperbaiki akan mengakibatkan kegagalan dalam menjamin keamanan dan kestabilan kehidupan keluarga. Oleh karena itu perlu diupayakan untuk selalu bersikap bijaksana dalam memenuhi kebutuhan keluarganya. Kegiatan pengabdian masyarakat ini dimaksudkan untuk memberikan pengetahuan kepada mitra sasaran yaitu ibu-ibu PKK RW 01 Cipayung Depok 1 tentang cara mengelola keuangan keluarga yang tepat melalui pelatihan dan pendampingan Metode yang digunakan dalam pelatihan ini adalah ceramah, tutorial, curah pendapat dan diskusi. Diharapkan setelah mengikuti pelatihan mitra dapat menyusun anggaran keluarga berdasarkan penghasilannya dan pengeluaran yang ditentukan dengan skala prioritas. Output yang diharapkan dari pelatihan ini adalah agar mitra termotivasi untuk menabung demi kesejahteraan keluarga yang lebih baik dan untuk bekal di masa depan.
\end{abstract}

Kata kunci: keuangan keluarga, pengelolaan keuangan, pelatihan. ibu-ibu PKK

\begin{abstract}
PKK RW 01 Cipayung Jaya Depok 1 group is a group of housewives, who in addition to filling their daily activities by carrying out PKK activities, their main duty as a wife is to manage all income / revenues, both routine and non-routine receipts and routine and non-routine expenses. everyday for the needs of his family. The problem of the PKK RW 01 Cipayung Jaya Depok 1 women group that is always being discussed is that there are posts that are over-budget so that there is a financial deficit at the end of the month or there are unmet needs. This condition if not corrected will result in failure in ensuring the safety and stability of family life. Therefore it is necessary to strive to always be wise in meeting the needs of his family. This community service activity is intended to provide knowledge to the target partners namely PKK RW 01 Cipayung Depok 1 women on how to manage family finances appropriately through training and mentoring. The methods used in this training are lectures, tutorials, brainstorming and discussions. It is expected that after attending training partners can develop a family budget based on their income and expenditure determined by priority scale. The expected output from this training is to motivate partners to save for better family welfare and for future stock.
\end{abstract}

Keywords: Family Finances, Financial Management, Training PKK 


\section{PENDAHULUAN}

Kelurahan Cipayung Jaya Depok merupakan bagian dari wilayah kota depok dengan jumlah penduduk sebesar 80.382 terletak dengan perbatasan sebelah Utara perbatasan Kelurahan Cipayung, Timur perbatasan Kelurahan Bojong Pondok Terong, Selatan perbatasan Kelurahan Citayem, Barat perbatasan Kelurahan Sawangan. Dari data demografi tahun 2017 kelurahan Cipayung Jaya rata rata berprofesi wiraswasta, bagian dari penduduk kelurahan Cipayung Jaya terdapat Kelompok PKK Rw 01 Cipayung Jaya Depok 1 merupakan kumpulan ibu-ibu rumah tangga, yang selain mengisi kegiatan sehari-harinya dengan melakukan kegiatan PKK tugas utamanya sebagai istri adalah mengelola semua pendapatan/penerimaan baik penerimaan rutin maupun tidak rutin dan pengeluaran rutin maupun pengeluaran tidak rutin sehari-hari untuk keperluan keluarganya. Masalah ibu-ibu kelompok PKK Rw 01 Cipayung Jaya Depok 1 yang selalu dibicarakan mengenai pengelolaan keuangan adalah adanya pos-pos yang over budget sehingga terjadi defisit keuangan pada akhir bulan atau adanya kebutuhan yang tidak terpenuhi. Kondisi ini jika tidak diperbaiki akan mengakibatkan kegagalan dalam menjamin keamanan dan kestabilan kehidupan keluarga.

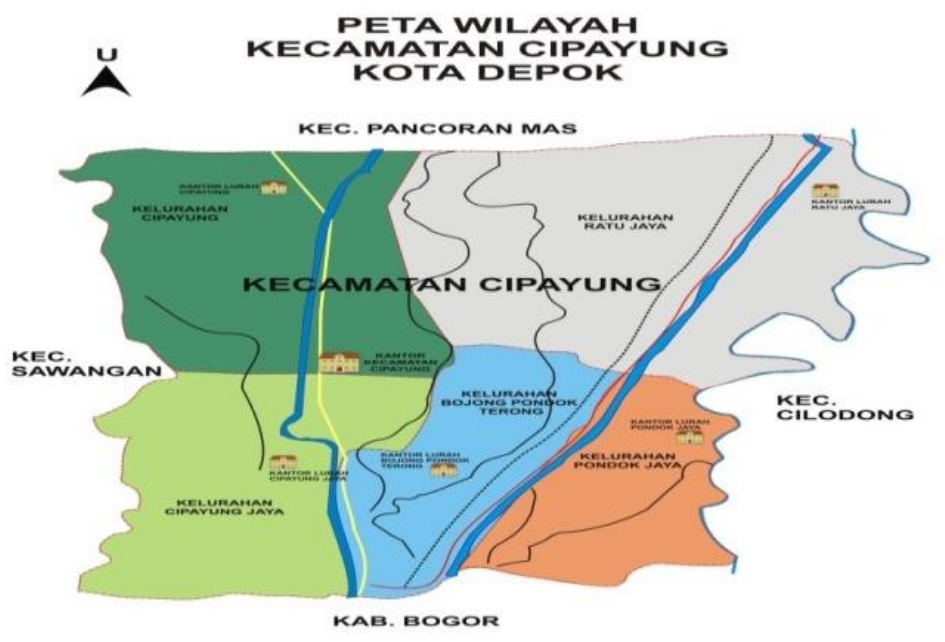

Gambar 1.1. Peta Wilayah Kecamatan Cipayung Kota Depok

Mitra dari kegiatan ini adalah Ibu Sahida Umur 55 tahun, alamat, Rt $01 \mathrm{Rw} 1$ berprofesi sebagai Ibu Rumah Tangga, dan Ibu Kusnia,Umur 50 ,alamat Rt 04 Rw 01 berprofesi sebagai Ibu Rumah Tangga.

Dalam menjalankan kegiatan usaha sehari hari masing-masing mitra masih belum dapat menggunakan pola pengelolaan keuangan yang sesuai dengan standar usaha. Keadaan demikian dapat memberikan dampak yang negatif dalam pemenuhan kebutuhan sehari-hari. Untuk mendorong Mitra menjadi keluarga yang layak maka diperlukan pengetahuan pengelolaan keuangan yang baik. Dalam kegiatan pengelolaan keuangan merupakan kegiatan yang tidak mudah maka perlu diadakan pelatihan pengelolaan keuangan yang sesuai dengan standar dasar yang baku

Berdasarkan analisis situasi tersebut maka dilakukan pelatihan tentang Peningkatan kapasitas pengelolaan manajemen keuangan keluarga khususnya kepada 
Kelompok PKK Rw 01 Cipayung Jaya Depok 1. Pelatihan ini diharapkan akan mampu memberikan bekal pengetahuan yang memadai dan di pergunakan sebagai dasar pengelolaan manajemen keuangan rumah tangga. Harapan pelaksana kegiatan adalah agar peserta mempunyai kemampuan untuk mengelola penghasilannya yang terbatas guna menutupi kebutuhannya secara rasional dan bijaksana sehingga dapat merubah perilaku lama dan akan membantu keluarga di lingkungan Kelompok PKK RW 01 Cipayung Jaya Depok 1. Tujuan yang ingin dijangkau oleh kegiatan ini adalah 1. Meningkatkan pengetahuan dan keterampilan keluarga kurang mampu dalam merencanakan dan mengelola keuangan keluarga. 2.Mempromosikan perilaku positif menabung, pengeluaran yang lebih bijaksana dan meminjam dengan alasan yang tepat.

\section{Pelaksanaan Kegiatan}

Waktu dan Lokasi Kegiatan IbM dilaksanakan selama 10 bulan, dimulai pada bulan Juli 2018 hingga bulan Juni 2019. Lokasi kegiatan yaitu di rumah ketua kelompok PKK Rt 01 RW 01 Kelurahan Cipayung Jaya Kecamatan Cipayung Depok 1 Jawa Barat. Alat dan Bahan Peralatan yang digunakan dalam kegiatan ini berupa Sound System, Screen, LCD, Laptop, Whiteboard kecil, Spidol dan Kertas plano

\section{METODE PELAKSANAAN}

Pelatihan ini mengikuti pendekatan pendidikan orang dewasa (adult learning). Peserta akan diberikan wawasan melalui metode ceramah, games, diskusi, berbagi pengalaman baik positif maupun pengalaman negatif dan menggali pelajaran baru bersama melalui studi kasus. Pelatihan mencakup kegiatan sebagai berikut:

1. Pelatihan

Kegiatan dilakukan dengan metode ceramah, tutorial, curah pendapat, diskusi. Ibuibu peserta diberikan wawasan mengenai pentingnya manajemen keuangan keluarga dan perilaku konsumsi yang bijaksana. Kegiatan dilakukan sebanyak 6x pada setiap hari Minggu. Materi yang diberikan adalah sebagai berikut:
a. Perkenalan
b. Kontrak Belajar
c. Manajemen Ekonomi Keluarga
d. Menetapkan Sasaran Keuangan Keluarga
e. Merencanakan Pengeluaran Keluarga
f. Manajemen Waktu
g. Pengelolaan dan Pengendalian Ekonomi Rumah Tangga

2. Pendampingan

Selama masa pelatihan dilakukan pendampingan kepada Ibu-ibu peserta dalam pengelolaan keuangan keluarga melalui metode konsultasi dan pengarahan. Kegiatan pendampingan sekaligus juga untuk mengetahui keberhasilan kegiatan.

3. Evaluasi

Evaluasi kegiatan dilakukan dalam dua tahap yaitu harian dan evaluasi akhir. Evaluasi dilakukan menggunakan kuesioner yang harus diisi oleh peserta. Kuesioner dibagikan setelah kegiatan pelatihan dilaksanakan. 
a. Evaluasi Harian

Formulir evaluasi harian diberikan kepada mitra di setiap akhir hari pelatihan. Ibu-ibu peserta mengisi kuesioner dengan cara memberikan tanda $(\sqrt{ })$.

Tabel 3.2 Kuesioner Evaluasi Harian

\begin{tabular}{|c|c|c|c|c|}
\hline No & Penilaian & Baik & Cukup & Perlu Peningkatan \\
\hline 1 & Isi pelatihan & & & \\
\hline 2 & Metode pelatihan & & & \\
\hline 3 & Kinerja Pelatih & & & \\
\hline 4 & & & & \\
\hline
\end{tabular}

b. Evaluasi Akhir

Kuesioner evaluasi akhir digunakan untuk mengetahui penilaian Ibu-ibu peserta terhadap seluruh kegiatan pelatihan. Peserta diminta untuk mengisi formulir dan dikumpulkan setelah pelatihan berakhir.

\section{PELAKSANAAN KEGIATAN}

\section{Materi I : Pembukaan dan Perkenalan}

a. Latar Belakang Pembukaan dan Perkenalan adalah untuk menciptakan suasana yang lebih resmi maka pembukaan dilakukan oleh ketua RW 01 dan untuk membangun kebersamaan dan saling memahami antar peserta sangat diperlukan dalam suatu proses belajar secara partisipatif. Dengan perkenalan diharapkan dapat membantu dalam menciptakan suasana yang mengarah pada kebersamaan dan keterbukaan antar peserta.

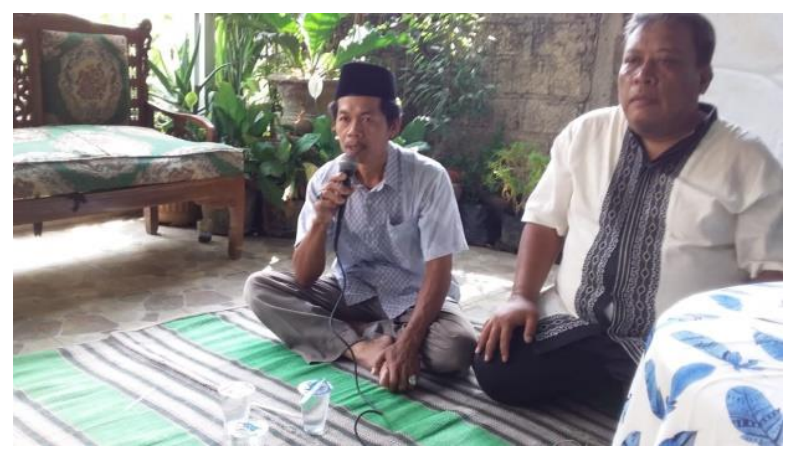

Gambar 4.1. Pembukaan dan Perkenalan

b. Tujuan Pembukaan dan Perkenalan adalah Menciptakan suasana yang lebih formal dan resmi, Agar tercipta suasana keakraban dan keterbukaan diantara peserta, Terbangunnya komunikasi yang kondusif dan partisipatif diantara para peserta. Peserta dapat membiasakan berbicara secara lugas tanpa rasa takut dan minder. 
c. Metodologi Pembukaan dan Perkenalan adalah Curah pendapat dan Perkenalan dengan cara urut

d. Proses acara pelatihan dibuka oleh Bapak Ketua RW. 01 dan Ketua PKK, Fasilitator mengenalkan diri dan menjelaskan materi yang akan dibahas dan tujuan yang ingin dicapai, Fasilitator meminta peserta untuk memperkenalkan diri: nama, nama suami, pekerjaan suami, dan masalah yang dihadapi dalam keuangan, Peserta menyampaikan permasalahan terkait dengan keuangan keluarga.

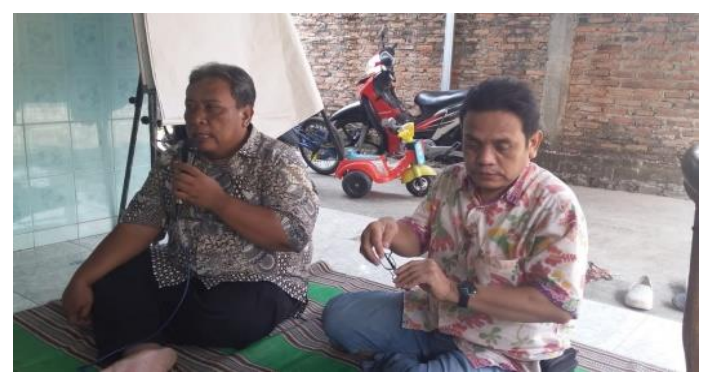

Gambar 4.2. Mengenalkan diri dan menjelaskan materi

e. Waktu Pelaksanaan: Minggu, 22 Juli 2018

f. Rangkuman Pembukaan dan Perkenalan adalah Peserta bersedia untuk mengikuti pelatihan, Peserta adalah ibu-ibu rumah tangga anggota kelompok PKK Rw 01 Cipayung Jaya Depok 1, Suami peserta ada yang berprofesi sebagai pedagang, karyawan swasta, PNS, supir angkot, buruh tani, Rata-rata peserta dikarunia 2-3 orang anak, Permasalahan peserta terkait dengan keuangan keluarga adalah: jumlah penghasilan yang terbatas, biaya hidup yang tinggi, biaya sekolah, terlibat hutang, Peserta berpartisipati aktif selama pelatihan berlangsung.

\section{Materi II: Kontrak Belajar}

a. Latar Belakang Kontrak Belajar adalah Menciptakan suasana akrab dan terbuka, mengungkapkan kehawatiran serta memunculkan harapan-harapan peserta yang merupakan proses sangat penting dalam sebuah proses pelatihan dan penciptaan suasana awal yang berpengaruh pada kebersamaan dan keterbukaan antar peserta, Materi dan jadwal berdasarkan kebutuhan peserta merupakan pondasi dasar kerangka serta prinsip dasar dalam pelatihan partisipatif, Membuat kesepakatan yang dapat saling mengikat dalam pelaksanaan proses belajar perlu dibangun.

b. Tujuannya Peserta dapat mengungkapkan harapan-harapannya terhadap pelatihan yang mereka ikuti ini, Peserta dapat mengungkapkan kehawatiran yang mungkin muncul didalam proses pelatihan, Mengidentifikasi kebutuhan - kebutuhan peserta dalam materi pelatihan, Mensepakati aturan - aturan selama proses belajar mengajar, Menyepakati jadwal belajar selama proses pelatihan.

c. Metodologi Curah pendapat, Diskusi tatap muka, Penjelasan langsung

d. Proses Kontrak Belajar adalah Fasilitator menjelaskan tentang materi yang akan dibahas dan tujuan yang ingin dicapai, Setiap peserta menyampaikan alasan mengapa mereka datang ke pelatihan ini, dan apa harapan peserta dalam mengikuti pelatihan ini, Fasilitator memimpin diskusi tentang alasan, harapan pada peserta, Fasilitator merangkum hasil diskusi ke dalam kertas plano, Fasilitator menentukan materi yang dibutuhkan oleh peserta pelatihan sesuai hasil diskusi, Fasilitator membuat 
kesepakatan tentang aturan-aturan yang harus dilaksanakan selama pelatihan, Fasilitator membuat jadwal pelatihan sesuai dengan kesepakatan yang telah diambil.

e. Pelaksanaan: Minggu, 29 Juli 2018

f. Rangkuman Kontrak Belajar Peserta dapat berpartisipati aktif dalam kegiatan selama pelatihan berlangsung, Alasan peserta mengikuti pelatihan adalah ingin mengetahui cara mengelola uang yang benar, Harapan peserta terhadap pelatihan: mendapat pengetahuan tentang cara mengelola uang yang benar, menghindari hutang yang tidak perlu, mendapat saran cara menambah penghasilan, Aturan yang disepakati bersama selama proses pelatihan: dating tepat waktu, jika tidak bisa hadir sesuai dengan jadwal yang ditentukan memberi tahu kepada fasilitator dan akan dicari pengganti pada hari lain, Adanya jadwal sesuai dengan kebutuhan bersama, yaitu hari Minggu mulai jam 13.00 siang.

\section{Materi III: Manajemen Ekonomi Rumah Tangga}

a. Latar Belakang pelatihan adalah Supaya setiap rumah tangga hidup dalam kesejahteraan, maka para anggotanya harus berupaya untuk memperbaiki ekonomi rumah tangganya, Upaya itu terutama tentang pengaturan keuangan keluarga, Pengaturan keuangan berarti dapat menyesuaikan antara uang masuk dengan uang keluar, Sering terjadi didalam rumah tangga, bahwa uang keluar lebih besar dari pada uang masuk, maka hidup seperti itu sulit untuk dapat mencapai hidup sejahtera, Supaya selalu ada sisa uang lebih diperlukan manajemen keuangan didalam keluarga. Ada dua cara yang dapat ditempuh: keluarga dapat mengendalikan uang keluar atau dengan meningkatkan kemampuan ekonomis rumah tangga.

b. Tujuannya Peserta mengetahui unsur-unsur manajemen ekonomi rumah tangga, Peserta memahami bahwa didalam rumah tangga dibutuhkan hidup dalam kesejahteraan, maka para anggotanya harus berupaya dapat memperbaiki ekonomi rumah tangga, Peserta dapat membuat rencana anggaran pendapatan dan pengeluaran didalam keluarga, Adanya kesadaran peserta untuk dapat memanfaatkan keterampilan yang dimiliki untuk meningkatkan pendapatan rumah tangganya

c. Proses pembelajaran Manajemen Ekonomi Rumah Tangga Fasilitator menjelaskan tentang materi yang akan dibahas dan tujuannya yang ingin dicapai, Fasilitator meminta peserta menyampaikan bagaimana pengalamannya selama ini dalam mengelola keuangan keluarga, Fasilitator menjelaskan bahwa tujuan hidup berumah tangga adalah keluarga sejahtera, aman, dan damai. Namun sering terjadi percekcokan didalam keluarga karena uang, Fasilitator menjelaskan unsur-unsur manajemen keuangan rumah tangga: penghasilan dan pengeluaran, Bersama peserta maka fasilitator menyimpulkan tentang kegiatan-kegiatan yang dapat dilakukan untuk peningkatan ekonomi rumah tangga.

d. Pelaksanaan : Minggu 5 Agustus 2018

e. Rangkuman keiatan Harus ada perencanaan pendapatan dan pengeluaran uang didalam keluarga, Pengeluaran harus disesuaikan dengan kondisi uang yang tersedia,

Monitoring dan evaluasi, untuk mengetahui apakah pendapatan cukup untuk memenuhi kebutuhan keluarga, Waktu yang masih tersisa diluar kegiatan utama dapat dimanfaatkan untuk meningkatkan pendapatan dalam rumah tangga sesuai 
dengan keterampilan yang dimiliki, Teridentifikasinya usaha-usaha yang dapat dilakukan oleh peserta untuk meningkatkan ekonomi rumah tangganya: mengambil konveksi (memasang kancing), membuat es mambo, beternak ayam kampung.

\section{Materi IV: Menetapkan Sasaran Keuangan Keluarga}

a. Pelaksanaan: 12 Agustus dan 19 Agustus 2018

b. Proses kegiatan : Langkah 1, Curah Pendapat, Pengalaman Pribadi Tentang Sasaran Hidup, Kepada peserta ditanyakan: apakah mereka memiliki sasaran-sasaran hidup? ,peserta diajak untuk bercurah pendapat mengenai sasaran hidup untuk mencapai tujuan hidup yang bahagia, dengan penekanan bahwa sasaran untuk mencapai tujuan hidup tersebut harus realistis dan kongkrit, contoh: ketika ditanya sasaran hidup, mereka mungkin akan menjawab "hidup kaya raya, mati masuk surga", hal ini adalah tujuan hidup yang sifatnya globa. Untuk itu, diajukan pertanyaan selanjutnya "bagaimana untuk mencapai tujuan tersebut?". Jawaban yang mungkin muncul adalah sasaran hidup, misalnya: memiliki kendaraan bermotor, mempunyai rumah besar, menyekolahkan anak, dll. Langkah 2: Latihan, Menetapkan dan Membuat Prioritas Sasaran Hidup. Peserta diajak untuk menutup mata selama 1 menit untuk membayangkan sasaran-sasaran hidup mereka. Setelah selesai, ditanyakan kepada peserta mengenai sasaran-sasaran hidup apa yang mereka inginkan. Jawaban peserta menunjukkan bahwa mereka memiliki banyak sasaran-sasaran dimana mereka akan membutuhkan sumber-sumber keuangan yang memadai. Selanjutnya ditanyakan apakah mereka dapat mencapai semua sasaran mereka pada waktu yang bersamaan. Semua peserta menjawab 'tidak'. Untuk itu, peseeta diminta untuk menyusun prioritas untuk menentukan mana yang ingin dicapai lebih dahulu dan mana yang ingin dicapai kemudian. Peserta diajak untuk membagi sasaran-sasarannya menjadi tiga prioritas: jangka pendek (0-1 th), jangka menengah (1-3th) dan jangka panjang (35th), dengan cara menuliskan atau menggambarkan sasaran-sasaran hidup mereka diatas kertas dengan tiga warna yang berbeda (warna merepresentasikan 3 jangka waktu yang berbeda) yang telah disediakan alat bantu dengan waktu pengerjaan selama 10 menit. Setelah selesai tempelkan balon-balon di kertas /dinding yang telah disediakan.

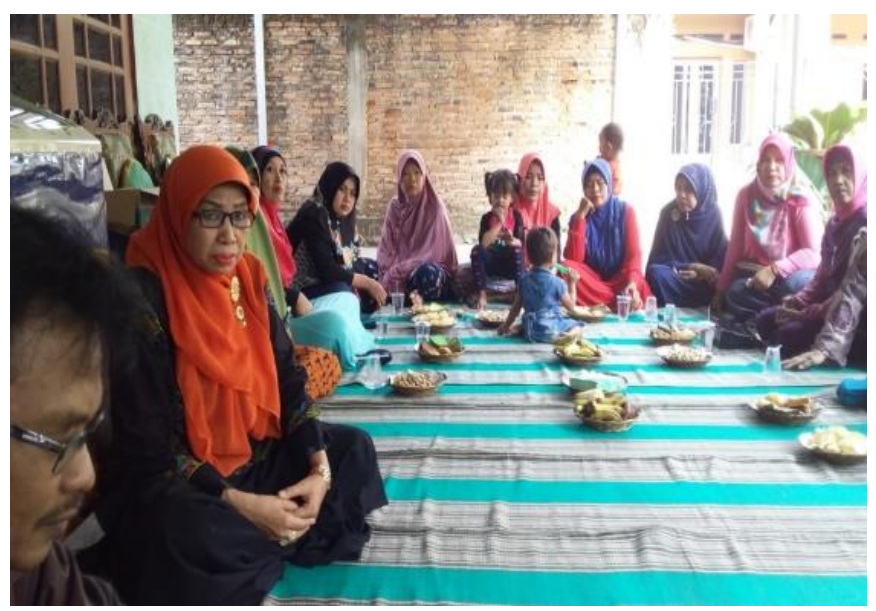

Gambar 4.3. Curah Pendapat, Pengalaman Pribadi Tentang Sasaran Hidup 
Langkah 3: Ceramah dan Latihan: Pentingnya Rencana Keuangan. Peserta ditanyakan: "Apa yang dapat dilakukan untuk menjamin bahwa sasaran-sasaran hidup yang anda inginkan akan menjadi kenyataan?". Pertanyaan ini menjadi dasar untuk mendiskusikan prinsip-prinsip dalam perencanaan keuangan. Jawaban peserta dirangkum meliputi: Menghitung jumlah uang yang akan dihasilkan dan dikeluarkan untuk memenuhi kebutuhan dasar keluarga, Menentukan biaya-biaya yang diperlukan untuk mencapai sasaran hidup, membuat keputusan tentang berapa banyak yang akan ditabung dan bagaimana membayar hutang, Menentukan waktu yang diperlukan untuk melakukan itu semua, Hal inilah yang disebut dengan Perencanaan Keuangan, Untuk memperkuat fokus kepada pencapaian pengelolaan kekuangan yang baik, isueisue pokok berikut ini juga dibicarakan: Manfaat membuat rencana keuangan, Pentingnya menentukan prioritas pengeluaran untuk masa depan, Membantu menghindari kekurangan dana yang tidak diharapkan, Membantu berdisiplin terhadap pengeluaran dan tabungan, Membantu mengurangi tekanan dalam masalah keuangan

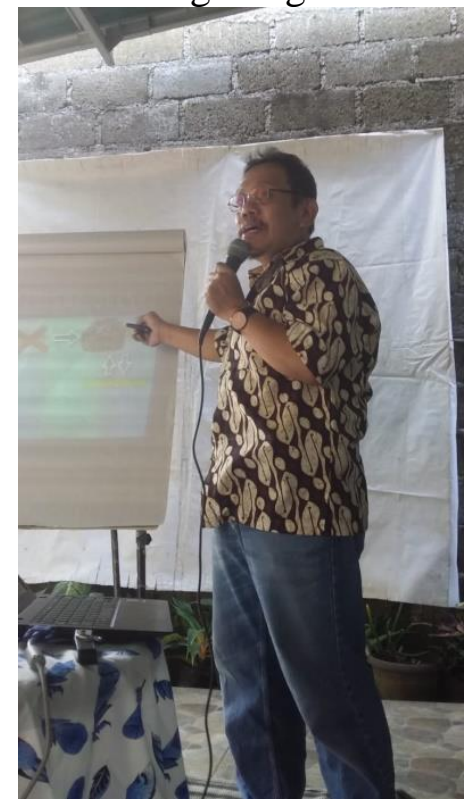

Gambar 4.4. Ceramah dan Latihan

Langkah 4: Kuis, Paradigma Umum dalam Mengelola Keuangan. Menjelaskan kepada peserta tentang paradigma umum dalam pengelolaan keuangan yang tidak selalu benar, sebagai contoh: banyak yang percaya bahwa mereka tidak dapat mengelola uang dengan baik karena tidak memiliki pengetahuan matematika yang baik; paradigma bahwa orang miskin tidak perlu menabung karena mereka tidak mempunyai uang, dsb, Peserta ditanya dan mendiskusikan mengenai paradigmaparadigma umum tersebut dan apakah ada paradigma-paradigma umum lainnya yang ada di lingkungan mereka. Kemudian dilanjutkan dengan pertanyaan berikut ini: Peserta diminta menjawab Benar atau Salah, Mengelola uang adalah rumit, Seseorang perlu menguasai matematika agar dapat mengelola uang dengan baik, Teman-teman saya akan meninggalkan saya jika saya menghasilkan uang lebih banyak dari mereka, Hutang saya terlalu besar dan saya tidak dapat melakukan apapun, Orang miskin tidak bisa menabung uang, Penting untuk menabung 
walaupun pendapatan saya kecil, Meskipun tabungan saya sedikit tetapi dapat meningkatkan stabilitas dan keamanan di masa depan, Tidak perlu membuat rencana keuangan karena uang tidak pernah cukup. Langkah 5: Rangkuman Pembelajaran. Peserta menjawab dengan tepat seluruh pertanyaan yang diajukan, Yang menarik dalam mengelola keuangan menurut peserta adalah: menjadi lebih disiplin, cermat dalam menggunakan uang dan berupaya untuk menambah penghasilan, Yang berguna bagi peserta dengan mengelola keuangan adalah: dapat menentukan sasaran pengeluaran dari jangka pendek, menengah hingga jangka panjang, Yang akan dipraktekkan peserta dalam kehidupan nyata: menentukan prioritas pengeluaran, membuat catatan penghasilan, Pokok-pokok kunci dalam sesi ini adalah: Menetapkan sasaran-sasaran keuangan dan Menyusun prioritas sasaran-sasaran keuangan

\section{Materi V: Merencanakan Pengeluaran Keuangan}

a. Latar Belakang Merencanakan Pengeluaran Keuangan yaitu Pentingnya perencanaan pengeluaran keuangan untuk mencapai sasaran, Pentingnya perencanaan keuangan untuk diseimbangkan dengan penghasilan.

b. Tujuan Belajar akhir sesi ini, peserta dapat: Menyusun dan mengelompokkan daftar pengeluaran keluarga, Menyebutkan permasalahan dalam menabung dan solusinya, Menyebutkan dan mengelompokkan sumber-sumber pendapatan keluarga, Menjelaskan manfaat membuat pembukuan sederhana

c. Pelaksanaan: 26 Agustus 2018

d. Proses kegiatan adalah Langkah 1: Curah Pendapat, Membuat daftar pengeluaran keluarga. Fasilitator menanyakan kepada peserta pertanyaan berikut: "Untuk apa anda membutuhkan uang?", "Pengeluaran apa saja yang sering terjadi pada keluarga Anda?' Peserta menulis dalam kartu- kartu berwarna jawaban mereka, Fasilitator menempelkan kartu jawaban peserta pada kertas plano dan mengajak peserta untuk berbagi pengalaman berkaitan dengan jawaban mereka, Fasilitator memastikan pengeluaran tidak terduga terdapat dalam jawaban tersebut. Jika tidak, tanyakan kepada peserta "keadaan darurat apa yang pernah dihadapi oleh keluarga mereka?". Jawaban dituliskan pada kertas yang disediakan dan ditempelkan di kertas plano, Fasilitator menjelaskan bahwa memisahkan pengeluaran antara untuk usaha (membeli peralatan, membeli bahan baku) dan pengeluaran untuk keluarga (biaya sekolah, membeli makanan, membayar listrik dan air, biaya darurat dan lain sebagainya) adalah penting ketika mengelola uang, Fasilitator meminta peserta untuk mengelompokan kartu-kartu yang berisi contoh-contoh pengeluaran menjadi 2 kategori, yaitu: pengeluaran untuk usaha dan pengeluaran untuk keluarga.

Langkah 2: Diskusi: Pengeluaran Tidak Rutin. Faslitator menanyakan dan membangun diskusi tentang apa yang dibayar sesekali saja atau tidak rutin?" Fasilitator memberi tanda cek pada pos pengeluaran-pengeluaran yang diidentifikasi oleh para peserta sebagai pengeluaran tidak rutin, Fasilitator meminta para peserta untuk mendiskusikan "Bagaimana mengantisipasi pengeluaran-pengeluaran yang tidak rutin, termasuk pengeluaran darurat", Jika ada hutang maka peserta diminta membuat jadwal membayar hutang yang paling besar terlebih dahulu, Fasilitator merangkum jawaban-jawaban peserta dan menyimpulkan bahwa salah satu hal yang penting ketika mengelola uang adalah membuat rencana untuk mengantisipasi pengeluaran-pengeluaran tidak rutin atau tidak terduga, misalnya menabung atau 
menunda pembelian-pembelian yang konsumtif. Langkah 3: Diskusi: Kesulitan Menabung. Fasilitator menanyakan kepada peserta: "kesulitan-kesulitan apa yang dihadapi ketika akan menabung? Peserta diminta untuk menuliskan pendapatnya di kertas plano, dilanjutkan dengan mendiskusikan jawaban-jawaban tersebut, Fasilitator merangkum jawaban-jawaban peserta dan menambahkan pokok-pokok berikut ini dalam diskusi: Mentukan berapa banyak uang yang dapat disisihkan untuk keperluan dana darurat, apakah disisihkan setiap hari atau setiap bulan dan pastikan tetap pada rencana tersebut, Fasilitator menjelaskan cara menabung yang baik, yaitu: menyimpan uang pada tempat yang aman, sebaiknya diluar rumah sehingga tidak mudah diakses.

Langkah 4: Diskusi, Sumber Pendapatan Keluarga. Fasilitator menanyakan dan mendiskusikan hal-hal berikut: Dari mana keluarga memperoleh pendapatan (uang)?, Siapa yang pendapatannya lebih banyak, apakah anda atau suami/istri anda?, Diantara sumber-sumber pendapatan, mana pendapatan yang tetap dan pendapatan yang tidak tetap?, Ketika memperoleh pendapatan yang besar, rencana apa yang akan dilakukan untuk menggunakannya, Fasilitator merangkum tanggapan-tanggapan dari peserta dan menyampaikan: Sangat menyenangkan apabila suatu saat kita memperoleh pendapatan dalam jumlah yang besar, Adalah penting untuk memikirkan bagaimana menggunakan uang tersebut secara bijak: untuk membayar hutang-hutang, memastikan dapat memenuhi kebutuan dasar dan menabung, untuk memenuhi pengeluaran-pengeluaran yang akan muncul dimasa yang akan datang. Langkah 5: Diskusi, Pencatatan Uang Masuk dan keluar, Fasilitator menanyakan dan mendiskusikan pertanyaan tentang bagaimana cara mengetahui jumlah uang masuk dan uang keluar?, Fasilitator menggali pengalaman-pengalaman dari peserta dalam hal: "siapa yang lebih mampu mengontrol uang masuk dan uang keluar, perempuan ataukah laki-laki ?" Mengapa?, Mendiskusikan keuntungan dan kesulitan yang akan dihadapi oleh peserta ketika mereka mencoba untuk melakukan pencatatan uang masuk dan keluar serta mendiskusikan solusi untuk mengatasi kesulitan tersebut. Langkah 6: Rangkuman Pembelajaran. Fasilitator mereview yang telah didiskusikan dalam sesi ini, meliputi: Peserta telah mempelajari: pengeluaran tidak rutin, kesulitan menabung, sumber sumber pendapatan keluaraga dan siapa diantara suami dan istri yang lebih terampil dalam mengelola keuangan keluarga, Yang dianggap menarik dan berguna untuk mengelola keuangan adalah cara menyisihkan uang untuk keperluan tidak rutin dan menabung, Peserta akan menabung meskipun sedikit untuk mengantisipasi pengeluaran tidak rutin sehingga tidak perlu berhutang.

Tabel 4.1 Macam-macam pengeluaran

\begin{tabular}{|c|c|}
\hline Pengeluaran Keluarga & Pengeluaran Usaha \\
\hline - Pembayaan biaya sekolah & - Hutang bisnis \\
\hline - Pembelian makanan, minuman & - Pembelian perabotan \\
\hline - Biaya air dan lisrik & - Pembelian bahan baku \\
\hline - Biaya tak terduga & $\begin{array}{l}\text { Pembayaran sewa, } \\
\text { kontrak, cicilan }\end{array}$ \\
\hline
\end{tabular}




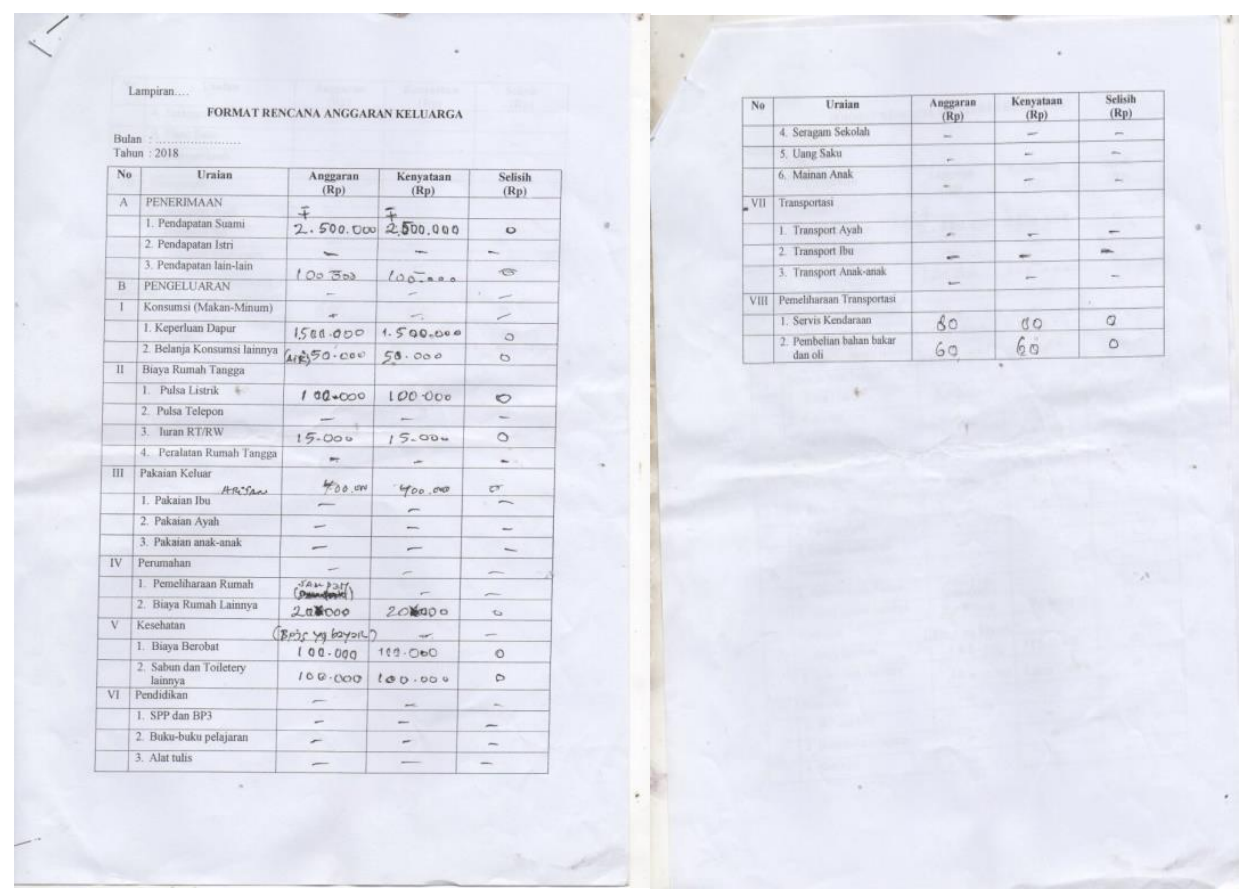

Gambar 4.5. Format rencana anggaran

\section{Materi VI: Manajemen Waktu}

a. Latar Belakang kegiatan adalah Waktu adalah satu-satunya sarana yang tidak dapat disimpan. Waktu terus berjalan dan tidak dapat dipanggil dan dimiliki kembali. Tiap orang hanya mempunyai waktu 24 jam sehari semalam, dan itupun termasuk waktu untuk tidur, Waktu adalah modal utama untuk menyelenggarakan berbagai kegiatan. Walaupun ada uang dan peralatan yang cukup, banyak banyak orang tidak bisa menyelenggarakan suatu kegiatan, hanya karena dia tidak punya waktu. Karenanya, waktu itu perlu diatur penggunaannya, Untuk menyelenggarakan berbagai kegiatan di dalam rumah tangga juga perlu pengaturan waktu, yang antara lain dengan membagi - bagi penggunaan waktu: ada waktu untuk bekerja, ada waktu untuk makan, untuk beribadah dan lain-lain.

b. Tujuan kegiatan Peserta dapat mengendalikan waktunya untuk kegiatan - kegiatan yang dapat bermanfaat, Dapat mengelola waktu yang tersedia, Dapat memanfaat waktu yang masih tersisa, dalam upaya peningkatan pendapatan keluarga, Peserta dapat mengidentifikasi usaha-usaha yang dapat dilakukan untuk meningkatkan ekonomi didalam keluarga.

c. Pelaksanaan 18 Maret 2017

d.. Metode: Penjelasan langsung. Penugasan, Diskusi

e.. Proses pelatihan Fasilitator menjelaskan materi yang akan dibahas dan tujuan yang ingin dicapai, Fasilitator membagikan kertas dan meminta peserta menuliskan kegiatan yang dilakukan mulai dari pagi, siang, sore dan malam harinya, Masingmasing peserta diminta untuk memabacakan jawabanya. Peserta lain diminta untuk memberikan komentar, fasilitator mencatat semua komentar dari peserta, Setelah diskusi selesai, fasilitator meminta peserta untuk menyampaikan ide/ sumbang tentang kegiatan kegiatan yang dapat menambah pendapatan dalam keluarga, Peserta 
dan fasilitator mengidentifikasi kegiatan atau usaha yang dapat dilakukan untuk memperbaiki ekonomi keluarga.

f.. Rangkuman kegiatan adalah Waktu berbeda dengan uang, waktu tidak dapat disimpan. Jadi ketika mempergunakan waktu harus cermat, artinya dapat menggunakan waktu secara tepat guna. Untuk menyelenggarakan berbagai kegiatan di rumah tangga diperlukan pengaturan waktu. Pengaturan waktu, antara lain berarti membagi-bagi penggunaan waktu: ada waktu untuk bekerja, ada waktu untuk berhandai-handai dengan anggota keluarga, ada waktu makan, untuk beribadah dan lain-lain. Dengan adanya pembagian waktu yang terencana dan jelas, maka peserta menyadari, masih ada waktu-waktu luang yang dapat dimanfaatkan untuk usaha ekonomi keluarga. Teridentifikasinya usaha-usaha yang dapat dilakukan untuk meningkatkan ekonomi keluarga: mengambil pekerjaan konveksi (memasang kancing, resleting, dll), memelihara ayam kampong.

\section{Materi VII: Pengelolaan dan Pengendalian Ekonomi Rumah Tangga}

a. Latar belakang pelatihan Pengelolaan dan Pengendalian Ekonomi Rumah Tangga yaitu Mengendalikan pengeluaran bukan berarti pelit, akan tetapi dapat mempertimbangkan secara hati-hati, sungguh-sungguh dan terbuka, setiap kegiatan (pengeluaran) yang akan dibiayai, Perlu diidentifikasi secara cermat: apakah kegiatan itu merupakan sesuatu yang dibutuhkan oleh keluarga atau hanya keinginan yang masih dapat ditunda, Mengembangkan keterampilan yang dapat menambah pendapatan rumah tangga, Menghindari hutang yang tidak perlu

b. Tujuan pelatihan : Peserta dapat mengelola dan mengendalikan keuangan rumah tangga, Peserta dapat membuat perencanaan pendapatan dan rencana pengeluaran rumah tangga, Peserta termotivasi untuk melakukan usaha-usaha alternatif dalam usaha meningkatkan pendapatan keluarga.

c. Metodologi pelatihan: Sumbang saran, Diskusi. Penugasan, Berbagi pengalaman

d. Proses pelatihan Fasilitator menjelaskan materi yang akan dibahas dan tujuan yang ingin dicapai, Fasilitator meminta peserta membagi pengalamannya dalam mengelola keuangan rumah tangga, Fasilitator mencatat pengalaman peserta di kertas plano dan membahasnya bersama, Fasilitator menjelaskan bahwa sering terjadi di dalam rumah tangga ada peribahasa "gali lobang tutup lobang", Fasilitator mencatat sumbang saran dari peserta menyikapi peribahasa tersebut di dalam kertas plano dan membahasnya bersama, Fasilitator menjelaskan didalam pengendalian dan pengelolaan ekonomi rumah tangga diperlukan "perencanaan pendapatan dan perencanaan pengeluaran", Fasilitator menjelaskan langkah-langkah dalam menyusun rencana anggaran pendapatan dan belanja rumah tangga sebagai berikut : Menyusun Daftar Perkiraan Pendapatan dan Menyusun Daftar Perkiraan Pengeluaran. Fasilitator meminta peserta menyebutkan manfaat pengelolaan dan pengendalian uang dalam rumah tangga, Fasilitator mencatat semua pendapat peserta di kertas plano, Fasilitator meminta peserta untuk membuat buku kas harian keluarga yang mencatat seluruh uang masuk dan uang keluar selama satu bulan, Bersama peserta fasilitator membahas manfaat atau kegunaan rencana anggaran pendapatan maupun pengeluaran.

e. Rangkuman pelatihan Pengelolaan dan Pengendalian Ekonomi Rumah Tangga adalah Upaya pengelolaan keuangan rumah tangga yang bijak menuntut adanya suatu perencanaan dan pengelolaan yang matang, Perwujudan upaya tersebut dapat dilakukan dengan cara menyusun rencana anggaran pendapatan dan biaya rumah 
tangga, Keluarga yang dapat menerapkan anggaran dengan baik, maka tidak akan pernah devisit bahkan ada kalanya ada kelebihan untuk ditabung. Dengan demikian keluarga tersebut telah keluar dari lingkaran "gali lobang tutup lobang ", Manfaat penyusunan anggaran pendapatan dan pengeluaran setiap bulan adalah:

- Keluarga terlatih hidup atas dasar rencana. Hal ini berpengaruh tidak hanya pada keuangan rumah tangga saja melainkan meluas pada kehidupan keluarga secara keseluruhan.

- Keluarga mampu berfikir reflektif sehubungan dengan tindakan sehari-hari dalam menjalani hidup berumah tangga.

- Ada dorongan bagi keluarga untuk menambah penghasilan melalui kegiatankegiatan yang produktif.

- Dapat meningkatkan rasa tanggung jawab seluruh anggota keluarga.

- Mempererat hubungan kerjasama di dalam anggota keluarga, karena tiap anggota keluarga terlibat dalam pengelolaan keuangan.

- Mendorong kemampuan ekonomis bagi keluarga dengan:

$\checkmark$ Adanya upaya untuk melakukan penghematan.

$\checkmark$ Adanya kemampuan untuk mengatur keseimbangan antara pendapatan dan pengeluaran.

$\checkmark$ Adanya keterampilan untuk memanfaatkan setiap kesempatan menambah pendapatan didalam keluarga.

- Tata cara penyusunan anggaran pendapatan dan biaya rumah tangga adalah sebagai berikut:

$\checkmark$ Merencanakan berapa penghasilan yang akan diperoleh pada priode tertentu, misalnya mingguan atau bulanan.

$\checkmark$ Merencanakan berapa macam kebutuhan yang muncul pada saat penerimaan penghasilan.

$\checkmark$ Menyeleksi mana yang merupakan kebutuhan dan mana yang merupakan keinginan.

$\checkmark$ Merencanakan anggaran tabungan saat menerima penghasilan.

\section{KESIMPULAN}

Dari kegiatan pelatihan yang telah dilakukan dapat disimpulkan beberapa hal terkait dengan pengelolaan keuangan dalam keluarga sebagai berikut:

1. Peserta (mitra) dapat mengikuti materi pelatihan dengan baik.

2. Hasil evalusai oleh peserta terhadap pelaksanaan pelatihan baik per materi (harian) maupun secara keluruhan baik.

3. Teridentifikasi kegiatan yang akan dilakukan oleh peserta untuk menambah penghasilan keluarga, yaitu: para ibu-ibu mulai menghidupkan kembali bank sampah yang pernah berhenti beroperasi karena terbatasnya pembeli, dan mulai memelihara ternak.

4. Peserta mulai menabung meskipun sedikit.

5. Peserta mempunyai motivasi untuk tidak berhutang terutama untuk pengeluaran yang sifatnya bukan kebutuhan utama/pokok.

6. Peserta mulai melakukan pencatatan terhadap penghasilan dan pengeluaran mereka. 


\section{DAFTAR PUSTAKA}

Hasibuan, M. (2005). Manajemen Dasar dan Masalah.

Masassya, E. G. (2004). Cara Cerdas Mengelola Investasi Keluarga. Jakarta: PT Elex Media Komputindo.

Noer, M. (2009). Kebiasaan Mencatat: Fondasi Dasar Perencanaan Keuangan.

Rodhiyah, R. (2012). Manajemen Keuangan Keluarga Guna Menuju Keluarga Sejahtera. In FORUM: Majalah Pengembangan Ilmu Sosial (Vol. 40, No. 1, pp. 28-33). Fakultas Ilmu Sosial dan Ilmu Politik, Undip.

Sanusi. (2012). Cara mengatur keuangan keluarga. Analisa Harian edisi 12 November. 